Original research article

\title{
Position of seniors in rural areas in relation to the Czech Republic
}

\author{
Renata Korcová *, Jana Borská \\ Czech University of Life Sciences Prague, Faculty of Economics and Management, Department of Law, Prague, Czech Republic
}

\begin{abstract}
The aim of this article is to characterize the legal position of seniors living in rural areas, and to research the question of whether the term "senior" is defined in the Czech legal system, and how the law deals with social exclusion and the possibilities of its elimination.

Methods used in this article include, in particular, legal analysis of selected legal texts. An additional technique was qualitative research enacted through the technique of focus groups with seniors living in the territory of the district of Strakonice and Český Krumlov, situated in the region of Southern Bohemia. There were in total 31 informants participating in the research, aged 65-74 years. The criteria for their choice are described in detail in the methodological section of this article.

The results of legal analysis have shown that the Czech jurisdiction does not include the definition of the term "senior", which can result in differing attitudes towards seniors in the Czech Republic that are based on their age (for example, the system of providing travel discounts to seniors is not unified in the individual regions of the Czech Republic). If the Czech state accepted the unambiguous term "senior", the rights of seniors would be unequivocally determined and there would not be discrepancies or even discrimination in treating seniors.

The legal analysis of the terms "position of seniors" and "social exclusion" has brought an interesting recommendation regarding which seniors should be informed. This area should be the responsibility of each municipality.

The qualitative research has shown that seniors view several fields as the crucial components of social exclusion in particular accommodation, leisure time, health and accessibility of social services.
\end{abstract}

Keywords: Czech Republic; Focus group; Population ageing; Rural areas; Senior; Social exclusion; Social services

\section{Introduction}

At present, Czech and European society is undergoing numerous changes. The most salient of these are demographic. This causes numerous changes which happen spontaneously in society, but others need to be enacted based on policies derived from the reflection of the problem and the possible risks of development. The dynamics of the current societal changes are so high that it is not only a problem to accommodate them, but also to understand, comprehend and accommodate them. The age structure of society is changing as the European and Czech population is getting older. A person is usually regarded as a senior when they are in a specific social and economic position which is determined by minimal financial security that enables the person to be outside of economic activity and grants them a huge amount of free time. At the same time, such a person is more vulnerable and dependent on health care. The economic situation of seniors is differentiated and such differentiation further increases. One of the outcomes of these societal changes is the increasingly debated term of social exclusion. It has its specific characteristics in relation to seniors.
Social exclusion on the one hand and social inclusion on the other hand are concepts that are relatively new to Czech society and the Czech legal system. They have only entered the generally accepted vocabulary of social policies in the last few decades - mainly in connection with the so-called European Social Charter. Age is one of the dimensions or risk factors that significantly increase the probability of social exclusion or that cause it directly. In addition to old age, other factors are longterm unemployment, low education, disability, homelessness, education of children in vulnerable families, drug addiction, etc. (Kotýnková and Laňka, 2002). "Social exclusions refer to the contexts created by the systematic hindrances to participation in activities" (Brabcová et al., 2016; Habib, 2015).

Population ageing-related prolongation of the length of human life affects all forms of human activity and all sectors of society. It does not concern only Czech society, but is also manifested in the European Union and worldwide, where states are considering or implementing corresponding "social security reforms" (Delavande and Rohwedder, 2017). Prolongation of life is associated not only with health conditions such as "advances in health and the controlling of communicable diseases" (Ghasemi et al., 2017), but also with improved housing fa-

\footnotetext{
* Author for correspondence: Renata Korcová, Czech University of Life Sciences Prague, Faculty of Economics and Management, Department of Law, Kamýcká 129, 165 21, Prague, Czech Republic; e-mail: korcova@pef.czu.cz http://doi.org/10.32725/kont.2019.049 
cilities, improving food quality (Kajanová and Vacková, 2015), living in peaceful conditions, etc. All of these factors contribute to "maintaining independence with ageing" (McGough and Zumsteg, 2014). Along with the improvement of living conditions, there is a need to face the economic issues associated mainly with social security and increased demands on the social security system. The economic result of population ageing is also caused by the changes in economic preferences, which have an impact on "the economic models of decision-making" (Sunde and Dohmen, 2016). Population ageing in rural areas is also determined by the migration of young people to cities. We find our study to be particularly timely and topical due to the fact that even though "the number of older people is rapidly increasing worldwide, they are still under-represented in research studies" (Cherubini and Gasperini, 2017).

It is also necessary to emphasise that in the last twenty years there has been obvious "convergence between the fields of social policy and urban geography through the reaffirmation that social disadvantage and locational disadvantage can be intertwined processes" (Engels and Liu, 2011). Socially excluded areas are closely linked with social exclusion. "These lo- calities are typically characterized by the low socio-economic status of their inhabitants, which is closely related to a symbolic exclusion and a high concentration of social-pathological phenomena" (Kajanová and Dvořáčková, 2011).

\section{Population ageing especially in the Czech Republic}

Ageing is a natural process in which time affects human beings. Population aging means situations when there are fundamental changes in basic demographic processes (i.e. increasing life expectancy, decline in birth rate and mortality, etc.). These go along with developments in individuals, such as changes in "social cognition skills" (Ansorena, 2017). Chart 1 shows the forecast of the development of the composition of the population of the Czech Republic until 2050. It is evident that a rapid increase in the $65+$ population ages is expected in the composition of the Czech population, along with a simultaneous reduction in the percentage representation of the economically-active population aged 15 to 64 . If the forecast is correct, it would lead to a situation where half of the population would be economically active and half economically inactive.

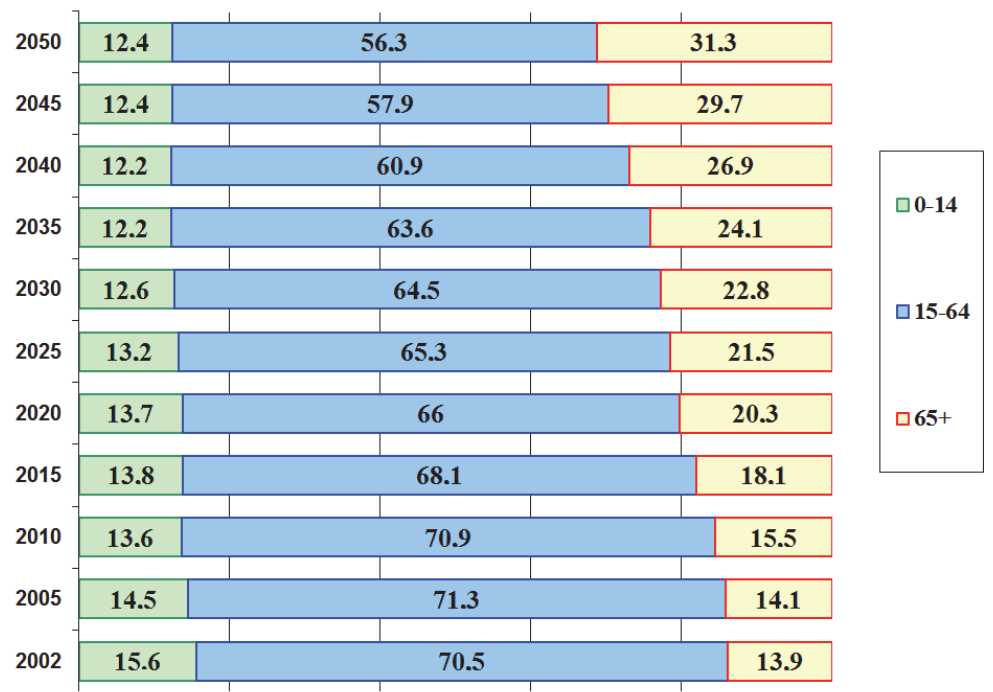

Chart 1. Prognosis of the age composition of the population of the Czech Republic until 2050 (in \%) (Šerák, 2013)

Population aging is not a phenomenon occurring only in the Czech Republic; this situation is referred to as problematic throughout the European Union. "This is not only a European phenomenon but a global phenomenon as well. In industrialized western countries a faster development is observable, yet in developing countries a trend towards longevity is recorded too" (Kurz, 2016). Unfortunately, demographic aging is not generally perceived as a commendable act of humanity and is instead presented as an economic problem. From the perspective of the European Union, the Czech Republic is not amongst the countries with the largest proportion of seniors. According to data from the Czech Statistical Office (2015a), of all the countries of the European Union the largest proportion of seniors (20.6\%) was in Germany (in terms of population, 2011). In the same year, in Austria, $17.6 \%$ of its population were seniors. In the Czech Republic, $15.5 \%$ of the population were seniors. The European country with the lowest number of people aged $65+$ was Ireland with $11.6 \%$ being seniors.

According to the German statistical office, on 31. 12. 2013, there were a total of $16.82 \%$ of people aged $65+$ (Das Statistik-Portal, 2013). In the Czech Republic it was $17.36 \%$ (Czech
Statistical Office, 2015a). In Austria the figure was $18.29 \%$ (Statistik Austria: Bevölkerung nach Alter und Geschlecht, 2017). These statistical indicators show that in terms of the representation of persons aged 65 years and older, all three neighbouring European countries are quite similar. "According to Eurostat, people aged 65 and older will make up $30 \%$ of the European Union population by 2060 - almost double the 2012 figure of $17 \%$. At the same time, the working age population (currently characterised as people aged 15-64 years), which peaked at $67 \%$ in 2010 , is predicted to decline steadily to $59 \%$ by $2060 "$ (Eurofound, 2016).

Another indicator that reflects the proportion of seniors in society and associated demographic aging is the so-called age index. This indicator shows the proportion of seniors aged $65+$ per 100 children under the age of 14 . In the Czech Republic, in 2011 the age index was at a value of 110.4 . This means that there were 100 persons aged $0-14$ years per 110.4 people aged 65+. The index was 122.4 in Austria and as high as 155.8 in Germany. The German value was the highest in the EU, and the lowest value was in Ireland at 50.0 (Eurostat, 2015). Chart 2 shows the population at the age of $65+$ in the overall population individual European states in 2014 in \%. 


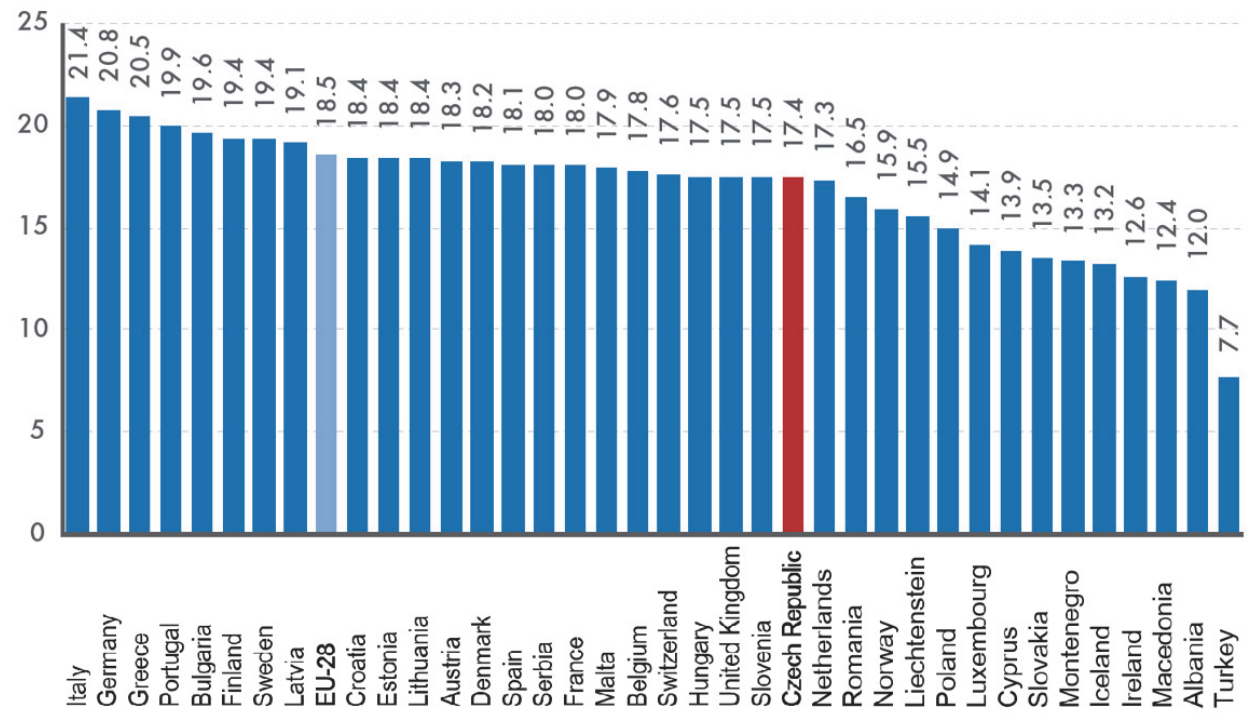

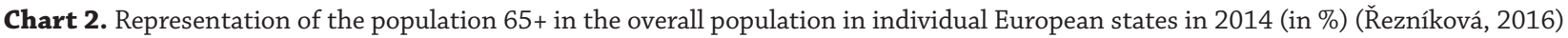

\section{Materials and methods}

The purpose of this article was to find out how the term senior is defined in the Czech legal system, including the issues related to social exclusion and the position of a senior. For the fulfilment of this purpose, the legal analysis of the accessible legislative documents dealing with seniors in the Czech Republic has been chosen. The legal analysis is methodologically very close to content analysis. However, its results are of explanatory nature, so they can be used for the promoting or defending of the rights of the target group. The results thus not only "bear" the information but they also lead to adopting certain measures in practice.

Data provided in this paper are gathered via outputs from the Czech statistical office (2015a), etc. In the comparison part, data about population ageing in rural areas of selected European countries neighbouring the Czech Republic (Germany and Austria) is used. For completeness, the paper also works with the Czech "National Action Plan on promoting positive ageing for 2013 to 2017" (hereinafter the "National Action Plan").

The second method which aimed to bring qualitative data related to the subjective apprehension of the position of seniors and of social exclusion was interviewing in particular the technique of a focus group, which was used for the purpose of determining the mainly subjective opinions of seniors in selected territories of the Czech Republic on their own position in society.

The selection of respondents was achieved by the method of deliberate selection of the research file, i.e. based on predetermined criteria: (1) Direct relationship to the rural areas; (2) Permanent residence in the district of Český Krumlov or the district of Strakonice (according to the specific group; (3) A person who has full legal capacity; (4) No family or similar relationship to another focus group respondent). Subjective opinions are herein viewed as important because it has been proven that elderly individuals "construct their meaning of independence which reflects their personal circumstances" (Barken, 2017). The focus group method was considered as particularly fitting for the purposes of this research because the relatively small number of participants does not result in "uncertainty regarding diagnostic accuracy” (Clegg et al., 2015).

In particular, the method of interconnection of external data and focus group technique is used to find out how social exclusion is perceived by the actors themselves.

The responses of the informants of the focus group were processed through open coding.

\section{Results}

\section{Legal analysis of the term senior in the Czech legislation}

In relation to the Czech Republic, it must be pointed out that no legal regulation specifies an official legal definition of a "senior" (the Charter of Fundamental Rights and Freedoms was assessed; the Constitution of the Czech Republic; the Act No 89/2012 Coll. as amended, the Civil Code; the Act No 108/2006 Coll. as amended, on social services). A senior is "most frequently a person considered to enter the stage of late adulthood when they are around 60-65 years old" (Działa, 2016). The most widely accepted limit is the UN approach, which in its documentation recognizes the age of 65 as the old age limit - often referred to as "65+".

\section{Legal analysis of the term "social exclusion" among the elderly in the Czech Republic}

According to Rawal (2008), social exclusion is characterized by limited access to institutions and services, spatial segregation, lack of contacts outside the excluded locality, exclusion from social networks, etc. In general, social exclusion (also known as exclusion or displacement) can be defined as the difficult life situation of an individual who is fully separated from mainstream society and social events, has difficulties accessing services and organizations and, depending on its severity, is prevented from returning back to normal society (Rawal, 2008). Socially excluded people often do not have enough contacts outside the socially excluded locality. The origin of the term social exclusion is Europe; the author of this expression is considered to be the French politician René Lenoir, who used 
the label "les exclus" for people living in poverty and individual groups of people who were excluded from the state system of social security (Rawal, 2008). He considered the following groups to be socially excluded: the mentally and physically handicapped, suicidal people, aged invalids, abused children, substance abusers, delinquents, single parents, multi-problem households, marginal, asocial persons, and other social "misfits". The types of social exclusion include spatial, cultural, economic, symbolic and other social exclusion.

Within the Czech legislation, social exclusion is defined as "the exclusion of a person from normal life in society, and the inability to participate in it as a consequence of an unfavourable social situation" [Act No. 108/2006 Coll., - § 3 Letter f)]. In the case of seniors, social exclusion can be understood as a lack of participation of a person (aged 65+) in social events and who is more dependent on the care of another person. Hoff (2008) presents a total of 15 factors that increase the risk of social exclusion of older people in the member countries of the European Union, where the Czech Republic is listed with reference to poor access to social services and social care, the absence of access to information technology and poor access to public transport.

According to the European Commission (2016), a total of 120 million people are at risk of poverty and social exclusion within the framework of the EU. However, by 2020 that number should drop to at least 20 million.

The issue of social exclusion was among the issues addressed by the Third Survey of the Quality of Life in Europe (EQLS) (Sándor et al., 2014, p. 7), which took place from September 2011 to February 2012 in a total of 27 EU member states. The EQLS research addresses the living conditions and social situation of citizens of the EU before and after the socalled economic crisis. For most of the countries under consideration, children are considered to be the main group at risk of poverty and social exclusion. In the Czech Republic, a survey was carried out in 2004 within the Czech Retirement Association (it included less than 1,000 respondents/seniors (Pernes and Solich, 2006). This survey revealed that only $5.4 \%$ of respondents had experienced discrimination, $4 \%$ had heard about it and $3.1 \%$ had read about it.

Hoff (2008) has identified a total of 15 factors that increase the risk of social exclusion of seniors in European Union Member States. The Czech Republic was mentioned in the area of poor access to social services and social care, lack of access to information technology and poor access to public transport.

In relation to the Czech Republic (and especially the South Bohemian Region), a survey was carried out in 2009 by Zimmelová et al. (2010). The main purpose of this survey was to map the needs of seniors in connection with the residential services offered by the largest city of South Bohemia - České Budějovice.

\section{Legal analysis of the term "position" of seniors}

The term "position of seniors" means that elderly people are a distinctive status group. As mentioned above, Czech law does not define the term "senior" or "elderly citizen" or any similar term. Yet, as in other countries, a number of Czech legislative regulations work with age limits, e.g. Act No. 155/1995 Coll., on Pension Insurance, Act No. 40/2009 Coll., Penal Code, Act No. 273/2008 Coll., on the Police of the Czech Republic, Act No. 169/1999 Coll., Prison Act, Act No. 361/2000 Coll., Road Traffic Act, Act No. 108/2006 Coll., on Social Services.

The most commonly used category of the breakdown of elderly people are (in terms of sociology) the early aged (senescence), aged 60 to 74 years; advanced age (senium) aged from
75 to 89 years; and longevity with a lower limit of 90 years (Malíková, 2011).

In the milieu of the Czech Republic, the aid and support of socially disadvantaged people is introduced mainly in the legislation of Act No. 108/2006 Coll., on Social Services. The aid and support modified in this act are to enable social inclusion for socially disadvantaged persons, or act preventively against eventual social exclusion, namely through the so-called social services. Social services form a component of the system of social security, specifically social assistance, which fulfils two basic functions: namely to prevent the emergence of poverty and to prevent the emergence of social exclusion. The basic activities in the provision of social services include, for instance, assistance in handling common tasks of care for oneself, assistance in personal hygiene or the provision of the conditions for personal, provision of food or assistance in assuring food, provision of accommodation, social therapeutic activities and others. In the Czech legal environment, social services are an "activity or a set of activities according to this Act, ensuring the assistance and the support to persons for the purposes of their social integration or prevention of their social exclusion" [Act No. 108/2006 Coll. - $\S 3$ Letter a)]. This is the way to assist and support socially disadvantaged people, which will provide them with social inclusion, or will act preventively against their eventual exclusion. Social services are provided in the form of social counselling, social care and social prevention services. A tool that allows individuals to finance the provision of social services is the care subsidy. It is a benefit that is provided to individuals who find themselves in an unfavourable social situation and dependent on the assistance of another person. The reason for introducing this form of aid was to allow the so-called dependent individuals to be assured of the necessary care when they need it. It is a tool of social inclusion, which is covered by the state budget, in which the state is directly involved in ensuring social services to handle the basic living needs of dependent individuals. Provision of social services in any form is more complicated in rural areas. The main problem here is the spatial separation from larger cities, where due to a higher concentration of people there is a broader range of social services without people having to commute.

\section{Qualitative research method - results}

Description of the selected regions for realizing the research In the second half of 2015, a survey was conducted using the focus group method, which focused on two groups of seniors from two regions of the Czech Republic. In terms of constitutional definition, the territory of the Czech Republic is divided into municipalities, which are the basic territorial self-governing units, and regions that are higher territorial administrative units. Municipalities and regions thus represent the official territorial division of the Czech Republic. Districts are a further division of the state, and are perceived as a statistical unit rather than as an administrative unit. Focus groups were conducted in two districts in the South Bohemian region, namely in the Strakonice district and the district of Český Krumlov.

The selection of the South Bohemian region was made on the basis of several selection criteria. The South Bohemian Region is one of the predominantly rural regions. In 2013 this region accounted for the highest share of gross value added in total, i.e. CZK 188.8 billion, out of a total of CZK 3,664.7 billion (Ministry of Agriculture of the Czech Republic, 2015). The share of unemployed persons in the South Bohemian region was $5.07 \%$ on 31 December 2015; so it is a region with a near-average value (Czech Statistical Office, 2015b). The 
reasons for the subsequent selection of Český Krumlov and Strakonice districts for carrying out the research consisted of two predefined criteria. The first criterion was the number of municipalities in these districts. Český Krumlov is the district with the lowest number of municipalities (46 municipalities) and the district of Strakonice has the highest number of municipalities in the region (112 municipalities) (Malíková, 2011). The second selection criterion was the location of the districts in the Czech Republic. A central district and one district on the border, i.e. peripheral district were chosen. Within the South Bohemian region there are three central districts (Písek, Strakonice and Tábor) and three peripheral districts (Český Krumlov, Jindřichův Hradec and Prachatice). In the district of Strakonice, there are a total of 112 municipalities and more than 70,000 residents live there. This is a so-called central district, which only shares borders with other districts of the Czech Republic. In the district of Český Krumlov, there are 46 villages and over 61,000 residents live there. This is a socalled peripheral district - besides other districts of the Czech Republic it also shares borders with Austria (namely the Austrian federal states of Lower Austria and Upper Austria).

\section{Description of the target group and selected criteria}

The two focus groups were attended by a total of 31 seniors; 15 from the district of Český Krumlov and 16 from the district of Strakonice (aged 65 to 74). The condition for participation in the research was to have two groups of seniors with a minimal number of 15 and a maximal number of 18 seniors. Each of the seniors-respondents had to fulfil four conditions, namely: (1) A direct relationship to the rural areas (measured by permanent residence in a village with a population of up to 2,000). (2) Permanent residence in the district of Český Krumlov or the district of Strakonice (according to the specific group). (3) A person who has full legal capacity. (4) No family or similar relationship to another focus group respondent. Both of the evaluated districts, i.e. the district of Strakonice and the district of Český Krumlov have experienced a different historical development, particularly within the last century when the district of Český Krumlov was among the areas affected by the displacement of Sudeten Germans and the subsequent gradual settlement. Based on the data found, it is, however, possible to state that this historical context does not have any essential impact on the present. The district of Český Krumlov is oriented on tourism, which can be seen to have strong potential for the future. The textbook example of successful integration of one ethnic group (the Roma) into the majority society is generally considered a great advantage of this district, especially in the town of Český Krumlov. The potential of the Strakonice district is still seen in its rather industrial character, because industry was one of the reasons for the development of the central town of Strakonice (especially the textile industry in connection with the former Fezko company, and the mechanical engineering industry associated with the Czech arms producer). The construction of a high-speed motorway connection (the current R4) in the locality of Nová Hospoda with the Czech-German border crossing Strážný would then be a great opportunity for the whole district.

\section{Results from the qualitative research (focus groups)}

The topics of the research were split into several areas using the method of clustering. Based on this method, the factors concerning social exclusion (and position) of seniors in rural areas were divided into several groups - i.e. the so-called central and more general categories, which reflect what seniors perceive as being important in terms of social exclusion (and what mostly affects social exclusion and their position). This included:

- Health

- Social services

- Status of elderly

- Leisure time and the related opportunities

\section{Health}

All of the respondents assessed their health as "worse", i.e. subjectively as acceptable, bad or very bad. Only one of the respondents assessed his own health as outstanding. The respondents evaluated health as an important factor that affects social exclusion and their position.

\section{Social services}

Several respondents said they could not do without the occasional help of a third person. These people most often relied on the help of family members or neighbours to improve their situation, and positively evaluated the approach of one or two generation younger neighbours. These activities have so far been performed for the elderly as a social service. The seniors judged it to be beneficial, but unfortunately also insufficient. Due to the inaccessibility of social services, they feel excluded.

\section{Status of the elderly}

Some of the interviewees consider themselves to be poor. In relation to rural life, the respondents cited several advantages of rural areas, which included a larger space, nature, contact with animals, calm and security. A few partial conclusions emerged from the research, which include a confirmation of the research question that seniors living in rural areas are suited to rural life, despite the disadvantages that the seniors perceived (e.g. unsuitable transport availability, distance to shops and doctors).

\section{Leisure time and the related opportunities}

It was not proven that seniors have sufficient leisure time activities. The majority responded that they were spending time in the garden adjacent to the family home. Only a small number of the seniors were informed by the local authorities on the possibilities of spending their leisure time in the nearby surroundings.

Before the research, it was assumed that seniors are among the socially excluded. However, the respondents in the research mainly considered themselves to be lonely rather than socially excluded. The seniors did not consider themselves to be discriminated against either.

\section{Discussion}

The results of legal analysis in the field of social exclusion have shown that the social exclusion of seniors, as stated in the previous sections of this article, were addressed mainly through Act No. 108/2006 Coll., on Social Services. The aim is to help the elderly return to normal society. However, if a senior is in poor health or living in an isolated senior home, such social inclusion is problematic. The reasons for the existence of spatial exclusion in the case of life in senior homes are the concentration of seniors in one facility and the location of homes for the elderly (they are often in areas outside the cities separated from ordinary social contacts). A common phenomenon is 'maladaptation' - the poor adaptation of the senior to a new, completely different environment. 
From the legal viewpoint, it is also very problematic that the term "senior" is not legislatively defined in the Czech legal system. This white spot is derived from the fact that seniors show certain weakening caused by age.

The basic recommendation is to help seniors live in their natural environment, while at the same time addressing their needs - ideally in the form of in the field social services. In this sense, it is recommended that these terrain social services are financially supported and economically preferred over residential social services. Emphasis must be placed on the individual approach to each senior. Another solution is to raise the awareness of seniors about the possibilities of active participation in society, especially by local public administration, e.g. by organizing regular meetings of members of the community with seniors, informing them of their rights and duties, leisure activities, social benefits, social services, changes in the Czech legal environment, etc. Social services and their accessibility seem to be key in the struggle against social exclusion (the same results have been yielded by the focus group discussions).

It is interesting to mention the research carried out in 2005 by respondents living in Czech municipalities with up to 2,000 inhabitants aged $18-64$. As with the focus groups respondents, the environment in the village and the appearance of the village are also positively evaluated within this research. The least positively evaluated are social life and especially employment opportunities. In terms of percentages, most people associate the countryside with with nature, tranquility and a healthy life, with the city being characterized by noise, culture and shops. Shopping was one of the negatives of life in rural areas raised in the focus groups (Majerová et al., 2007, p. 15, 121).

In relation to leisure time it is possible to mention further research. In a survey conducted in 2005, in which data was collected by STEM non-profit institute (STEM, 2005), respondents were asked about their way of life. The most common responses of people aged 65+ were the countryside, the garden, and small animals. The majority of respondents in the focus group in the same age group responded in this way. "Of the 290 people over the age of 65 , there were also the most (almost $30 \%$ ) who claim to live a traditional rural life, i.e they spend most of their time on the domestic economy, farm fields or larger gardens over 5 acres" (Majerová et al., 2007, p. 86).

On the issue of discrimination, it is possible to introduce other research. A 2009 European Social Survey (Round 4) data (Trusinová, 2013) showed that age discrimination is experienced in $54 \%$ of the population in the Czech Republic, with a 33\% figure within Europe. The Czech Republic ranks first among 28 selected countries in the proportion of people experiencing discrimination due to age, with $62 \%$ of people reporting a lack of respect due to age. Approximately half of the respondents felt bad behavior due to age, particularly in the form of insults or refusing to provide a service (Trusinová, 2013). "The youngest and oldest age groups have the most common experience of age discrimination; Czechs aged 15 to 29 experienced a lack of respect in $70 \%$ of cases, seniors over 70 years of age in 67\%" (Trusinová, 2013). On the other hand, those with the least experience of lack of respect are about 40 years old (50\%, see Trusinová, 2013, p. 27). Inappropriate behaviour such as insulting or rejecting services were often experienced by young people under the age of 29 as well as by seniors over 70 (57\% of them). People of about thirty-one years old (44\%) have the least of these negative experiences" (Trusinová, 2013, p. 32). Age discrimination is fairly widespread, with the seniors among the vulnerable group, but it always depends on the specific situation. In relation to this partial research question, it can be concluded that the focus group respondents were mostly among those who do not feel subjectively discriminated against.

Within the Association of Pensioners of the Czech Republic (Šerák, 2013), an orientation survey was carried out in 2004, in which almost 1000 respondents/senior citizens participated. It was found in this survey that "only $5.4 \%$ of respondents had met with discrimination, $4 \%$ had heard about it, and $3.1 \%$ were reading about it. It is gratifying that $87.5 \%$ of respondents did not face this inappropriate action" (Šerák, 2013).

Increasing the awareness of seniors, especially seniors living in rural areas, would certainly contribute to improving at least their mental state. It would also help, to some extent, to reduce the criminal activity committed against seniors and to recognize the "human capital of older workers" in spite of the fact that their "workforce preferences" evolve with age (Bowlus et al., 2016).

Neither social exclusion nor poverty can be eradicated in society, but it is possible to take steps to reduce them for the prosperity of the whole society. Preventing and "alleviating social isolation and loneliness among older people is an important area for policy and practice" (Cattan et al., 2005). It is also necessary to state that the increase of the average age of the Czech citizens and the related ageing of the population certainly brings a significant effect in the prolongation and improvement of human life, but also causes an increase in the number of inhabitants, overpopulation, increasing demand for raw material resources, the expansion of areas of human activities, etc.

\section{Conclusions}

The results of the legal analysis have shown that the Czech legal system does not include the definition of the term "senior", which can cause differentiated attitudes towards seniors of different age in the Czech Republic (for example, the system of providing discounts in public transport in individual regions of the Czech Republic is not unified). If the Czech state accepted a unified legal interpretation of the term "senior", the rights of seniors would be defined in relation to age and there would not be unequal treatment and in some cases discrimination.

The legal analysis of the term "position" and "social exclusion" has yielded an interesting recommendation about which seniors should be informed. This is a field where the municipalities should once again reaccept their responsibility. The qualitative research has shown that seniors understand several areas as crucial in contributing to social exclusion - particularly accommodation, leisure, health and the accessibility of social services.

For the position of seniors and their health and mental states, their perception in their own family is very important. At the time they leave their employment and old social groups they mainly need to overcome a feeling of worthlessness and evoke their own importance. It is necessary to emphasize that the group of seniors is not a homogeneous group. Individuals of advanced age, who are entirely self-sufficient, active and sociable, appear in it. On the other hand, there are also people represented here with whom there was or is such a loss of functional potential that they are directly dependent on the assistance of another person to meet their basic needs. Mostly this group should be given both preventive and subsequent care in an effort to resolve their social situation. Such assistance can be both economically oriented assistance characterized by higher social benefits - which would enable the necessary 
seniors as normal a life as possible, but also social therapeutic activities, e.g. by spending time with the elderly, the implementation of various ways of filling their free time, etc. A lot of seniors, especially in rural areas, live in conditions that are not entirely appropriate to their health condition. Even in the group of seniors surveyed, some reported moisture in the family house, mould or problems with physically handling the operation of the boiler for hot water or the boiler for heating. With regard to the limited accessibility of social services in the rural areas, assistance should be directed to families, and also to the self-administration in municipalities that should help their citizens.

The role of municipalities in assisting seniors will certainly grow. The research has shown that seniors feel a lack of inclusion in public and social life - in particular in rural areas, where inclusion is usually the only opportunity to get involved in social life.

\section{Conflict of interests}

The authors have no conflict of interests to declare.

\section{Postavení seniorů ve venkovských oblastech v České republice}

\section{Souhrn}

Cílem tohoto článku je charakterizovat právní postavení seniorů žijících ve venkovských oblastech a zkoumat otázku, zda je v českém právním systému definován pojem „senior“ a jak zákon řeší sociální vyloučení a možnosti jeho eliminace.

Metody použité v tomto článku zahrnují zejména právní analýzu vybraných právních textů. Dále byl použit kvalitativní výzkum provedený na skupině seniorů žijících v okresech Strakonice a Český Krumlov v jižních Čechách. Výzkumu se zúčastnilo 31 osob ve věku 65-74 let. Kritéria pro jejich výběr jsou podrobně popsána v metodické části článku.

Výsledky právní analýzy ukázaly, že česká jurisdikce nezahrnuje definici pojmu „senior“, což může být v České republice příčinou rozdílných postojů vǔči seniorům, v závislosti na jejich věku (například systém slev při cestování není pro seniory v jednotlivých regionech České republiky sjednocený). Pokud by Česko přijalo jednoznačný termín „senior“, práva seniorů by byla jasně stanovena a při zacházení s nimi by nedošlo $\mathrm{k}$ rozporům nebo dokonce $\mathrm{k}$ diskriminaci.

Právní analýza pojmů „postavení seniorů“ a „sociální vyloučení“ přinesla zajímavé doporučení ohledně informovanosti seniorů, za kterou by měly odpovídat obce.

Kvalitativní výzkum ukázal, že senioři považují za klíčové složky sociálního vyloučení zejména ubytování, volný čas, zdraví a dostupnost sociálních služeb.

Klíčová slova: Česká republika; fokusní skupina; senior; sociální služby; sociální vyloučení; stárnutí populace; venkov

\section{References}

1. Act No. 108/2006 Coll., on Social services. In: Sbírka zákonů České republiky, částka 37, pp. 1257-1289.

2. Act No. 155/1995 Coll., Pension insurance. In: Sbírka zákonů České republiky, částka 41/1995.

3. Act No. 169/1999 Coll., Prison act. In: Sbírka zákonů České republiky, částka 58/1999.

4. Act No. 273/2008 Coll., on the Police of Czech Republic. In: Sbírka zákonů České republiky, částka 91/2008.

5. Act No. 361/2000 Coll., Road traffic act. In: Sbírka zákonů České republiky, částka 98/2000.

6. Act No. 40/2009 Coll., Penal code. In: Sbírka zákonů České republiky, částka 11/2009.

7. Act No. 89/2012 Coll., The Civil code. In: Sbírka zákonů České republiky, částka 33/2012.

8. Ansorena X (2017). Social cognition: development across the life span. RASP 5(2): 203-206. DOI: 10.17583/rasp.2017.2728.

9. Barken R (2017). 'Independence' among older people receiving support at home: the meaning of daily care practices. Ageing Society 46: 1-23.

10. Bowlus AJ, Mori H, Robinson C (2016). Ageing and the skill portfolio: evidence from job based skill measures. JEoA 7: 89-103. DOI: 10.1016/j.jeoa.2016.02.003.

11. Brabcová I, Trešlová $M$, Bártlová $S$, Vacková J, Tóthová $V$, Motlová L (2016). Risk factors for malnutrition in seniors aged 75+ living in home environment in selected regions of the Czech Republic. Cent Eur J Public Health 24(2): 91-94. DOI: 10.21101/cejph.a4283.

12. Cattan M, White M, Bond J, Learmouth A (2005). Preventing social isolation and loneliness among older people: a systematic review of health promotion interventions. Ageing Society 25(1): 41-67. DOI: 10.1017/So144686X04002594.
13. Cherubini A, Gasperini A (2017). How to increase the participation of older subjects in research: good practices and more evidence are needed! Age Ageing 46(6): 878-881. DOI: $10.1093 /$ ageing/afx123.

14. Clegg A, Rogers L, Young J (2015). Diagnostic test accuracy of simple instruments for identifying frailty in communitydwelling older people: a systematic review. Ageing Society 44(1): 148-152. DOI: 10.1093/ageing/afu157.

15. Czech Statistical Office (2015a). [online] [cit. 2016-01-15]. Available from: http://www.czso.cz

16. Czech Statistical Office (2015b). Podíl nezaměstnanosti podle krajů. [online] [cit. 2016-01-25]. Available from: https://www. czso.cz/csu/xc/animovana_mapa_podil_nezam_kraje

17. Das Statistik-Portal (2013). Bevölkerung - Zahl der Einwohner in Deutschland nach Altersgruppen am 31. December 2013. [online] [cit. 2015-05-29]. Available from: http://de.statista. com/statistik/daten/studie/1365/umfrage/bevoelkerungdeutschlands-nach-altersgruppen/

18. Delavande A, Rohwedder S (2017). Changes in spending and labour supply in response to a Social Security benefit cut: Evidence from stated choice data. JEoA 10: 34-50. DOI: 10.1016/j.jeoa.2017.09.001.

19. Działa B (2016). Artistic activity among the elderly as a form of lifelong learning, based upon the opinions of the University of Wrocław's University of the Third Age handicraft group members. JECS 2016(1): 144-151. DOI: 10.15503/ jecs20161.144.151.

20. Engels B, Liu G-J (2011). Social exclusion, location and transport disadvantage amongst non-driving seniors in a Melbourne municipality, Australia. J Transp Geogr 19(4): 984-996. DOI: 10.1016/j.jtrangeo.2011.03.007, p. 984.

21. Eurofound (2016). Overview: Work, care and inclusion of older people. [online] [cit. 2016-03-06]. Available from: http://www. eurofound.europa.eu/cs/node/4268 
22. European Comission (2016). Poverty and social exclusion. [online] [cit. 2016-03-22]. Available from: http://ec.europa.eu/ social/main.jsp?catId $=751$

23. Eurostat (2015). [online] [cit. 2015-05-20]. Aviable from: http://ec.europa.eu/eurostat

24. Ghasemi S, Keshavarz Mohammadi N, Mohammadi Shahboulaghi F, Ramezankhani A (2017). A critical review of studies on health needs assessment of elderly in the world. Elderly Health Journal 3(1): 1-9.

25. Habib KN (2015). An investigation on mode choice and travel distance demand of older people in the National Capital Region (NCR) of Canada: application of a utility theoretic joint econometric model. Transportation 42(1): 143-161.

26. Hoff A (2008). Tackling poverty and social exclusion of older people - lessons from Europe. [online] [cit. 2014-12-23]. Available from: http://www.ageing.ox.ac.uk/files/Working\%20 Paper\%20308.pdf

27. Kajanová $\mathrm{A}$, Dvořáčková $\mathrm{D}$ (2011). Sociálně vyloučená lokalita očima jejích obyvatel. Kontakt 13(4): 419-424.

28. Kajanová A, Vacková J (2015). Selected parameters of social exclusion among immigrants in the Czech Republic. Neuroedocrinol Lett 36 (Suppl. 2): 43-47.

29. Kotýnková M, Laňka Š (2002). Národní akční plány boje proti chudobě a sociálnímu vyloučení členských zemí Evropské unie. Prague: VÚPSV, p. 6.

30. Kurz R (2016). Senior theatre an important part of senior culture. JECS 2016(1): 152-164. DOI: 10.15503/ jecs20161.152.164.

31. Majerová V, Herová I. et al. (2007). Český venkov 2006: sociální mobilita a kvalita života venkovské populace. Prague: $C$ zech University of Life Sciences.

32. Malíková E (2011). Péče o seniory v pobytových sociálních zařízeních. Praha: Grada, p. 14.

33. McGough EL, Zumsteg JM (2014). Lifestyle changes in the prevention of mobility disability. Healthy Aging \& Clinical Care in the Elderly 6: 33-41. DOI: 10.4137/HACCE.S12502.
34. Ministry of Agriculture of the Czech Republic (2015). Zpráva o stavu zemědělství ČR za rok 2014 "Zelená zpráva”. [online] [cit. 2016-01-24]. Available from: http://eagri.cz/public/web/ file/418681/Zprava_o_stavu_zemedelstvi_CR_v_roce_2014.pdf

35. Pernes Z, Solich J (2006). Diskriminace seniorů z pohledu Rady seniorů ČR. In: Sborník z mezinárodní conference Postavení a diskriminace seniorů v České republice. Praha: Ministerstvo práce a sociálních věcí, pp. 45-50.

36. Rawal N (2008). Social inclusion and exclusion: a review. Dhaulagiri Journal of Sociology and Anthropology 2: 161-180. DOI: 10.3126/dsaj.v2i0.1362.

37. Řezníková J (2016). Evropští senioři se stát od státu liší. Statistika \& My 6(1): 22-23.

38. Sándor E, Ahrendt D, Kuenzi R (2014). 3rd European quality of life survey: quality of life in Europe: families in the economic crisis. Luxembourg: Publications Office, p. 7.

39. Šerák M (2013). Senioři jako specifická cílová skupina - výzva pro knihovny; June 2013. [online] [cit. 2015-04-12]. Available from: http://www.skipcr.cz/akce-a-projekty/dokumenty/8.valna-hromada-skip-2013/serak.ppt

40. Statistik Austria: Bevölkerung nach Alter und Geschlecht (2017). [online] [cit. 201705-20]. Available from: http://www. statistik.at/web_de/statistiken/menschen_und_gesellschaft/ bevoelkerung/bevoelkerungsstruktur/bevoelkerung_nach_ alter_geschlecht/index.html

41. STEM (2005). [online] [cit. 2016-01-24]. Available from: https://www.stem.cz/

42. Sunde U, Dohmen T (2016). Ageing and preferences. JEoA 7: 64-68.

43. Trusinová R (2013). Ageismus a mezigenerační vztahy. In: Vlachová K (Ed.). Hodnoty, postoje, chování: Česká republika 2002-2012: sociální report projektu European Social Survey. Prague: Institute of Sociology of the Czech Academy of Sciences.

44. Zimmelová P, Kozlová L, Kovárnová Š, Kostohryz D, Šachtová Z (2010). Analýza současného stavu pobytových služeb pro seniory v Českých Budějovicích. Kontakt 12(3): 298-306. DOI: 10.32725/kont.2010.041. 